\title{
No-till Vegetable Production at the Cal Poly Organic Farm
}

A Thesis Presented to the Faculty of the California Polytechnic University, San Luis Obispo

In Partial Fulfillment of the Requirements for the Degree of M.S. in Agriculture, Specialization in Crop Science

by

Nathaniel Harkleroad

December 2010 
(C) 2010

Nathaniel Jay Harkleroad

ALL RIGHTS RESERVED 


\section{Committee Membership}

TITLE: No-till Vegetable Production at the Cal Poly Organic Farm

AUTHOR: Nathaniel Jay Harkleroad

DATE SUBMITTED: December 2010

COMMITTEE CHAIR: Dr. John Phillips, Ph.D.

COMMITTEE MEMBER: Dr. Christopher Appel, Ph.D.

COMMITTEE MEMBER: Dr. J. Wyatt Brown, Ph.D. 


\section{Abstract \\ No-till Vegetable Production at the Cal Poly Organic Farm \\ Nathaniel Jay Harkleroad}

Tillage and subsequent bare soil have been linked to erosion, nutrient leaching, reduced biological diversity, loss of organic matter, and release of $\mathrm{CO}_{2}$ into the atmosphere (Brady and Weil, 2004). The usefulness of an organic no-till system for transplanted vegetables was explored over two growing seasons. In 2007-2008, in a randomized complete block design, treatments of tilled and no-till (T and NT, respectively) were seeded to a dense grain and legume winter cover crop. Tilled plots were mown and diskploughed two times; NT plots retained a mow-killed mulch on the soil surface. There were less weeds in NT plots. A corollary experiment was conducted in 2007-2008 to help determine the best cover crops for a no-till system. There was no difference in the amount of biomass produced by the different cover crops, although anthesis for 'Juan' triticale (Triticum X Secale) was 12 days later than for 'Montezuma' red oats (Avena sativa). In 2008-2009, a completely randomized experimental design was used to test the effect of tillage on bell pepper yield, weed suppression, plant height, and total soil carbon. The treatments were tilled and no-till ( $\mathrm{T}$ and NT, respectively). A winter cover crop was seeded. Tilled plots were mown, hand-forked and roto-tilled; NT plots retained a killed mulch on the soil surface. Although T plots yielded more bell peppers, NT plots had more weed suppression. There was no difference between the treatments in the change of total soil carbon over the 1 year period, although both treatments experienced overall gains. The present study will add to the growing body of research on the possibility of organic no-till vegetable farming for small- to mid-sized growers located on the central coast of California.

Keywords: no-till, conservation tillage, organic production, cover crop, bell pepper 


\section{Acknowledgements}

This research would not have been possible at Cal Poly without the support of Dr. John Phillips, who not only was kind enough to take me on as a graduate student, but also challenged me to think about sustainable crop production in many novel ways. I would be remiss not to mention Brad Booker for giving me the idea of organic no-till vegetable production as a topic of inquiry and for all of his practical farming advice. I am indebted to the staff of the Cal Poly Organic Farm for giving me a space to perform research, in addition to providing me employment for nearly four years, and ample opportunity to improve my ability to farm. Indeed, without the Cal Poly Organic Farm, my education would have been incomplete at Cal Poly. There I found the real world application of what I learned in the classroom. Many thanks to my committee members for their guidance in my course planning and for reading drafts of this work. Lastly, I would not be where I am today without the support of my wonderful friends and family--especially my wife, Maria, and son, Oliver, who came into this world during the middle of it all. 


\section{Table of Contents}

Page

List of Tables ....................................................................................................... vii

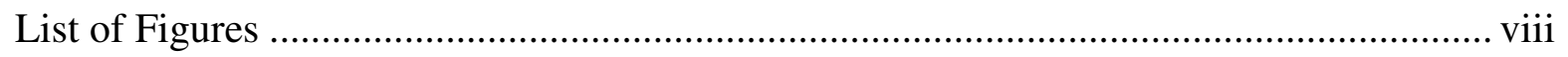

Section

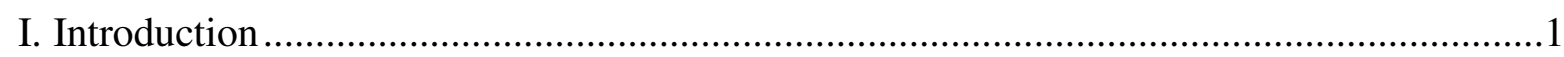

Importance of the Project................................................................. 2

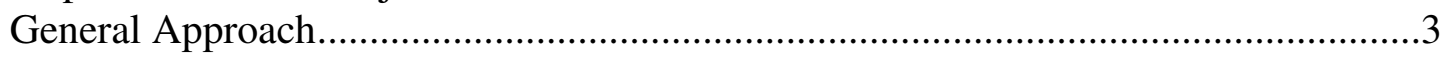

II. Literature Review ..............................................................................................

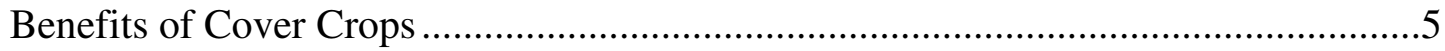

Killed-Cover-Crop Mulch Vegetable Production Systems ........................................6

Weed Suppression in Organic No-till Vegetable Production......................................8

Yield in Organic No-till Vegetable Production..................................................... 10

Soil Organic Carbon in No-till Vegetable Production

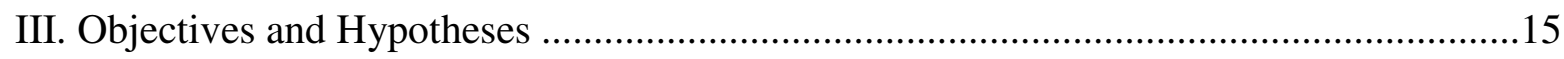

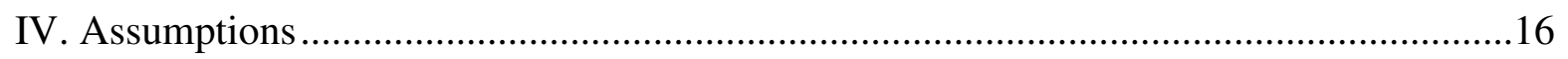

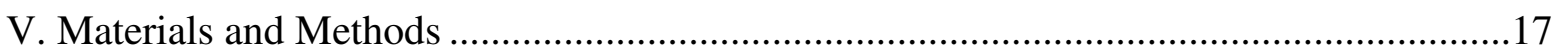

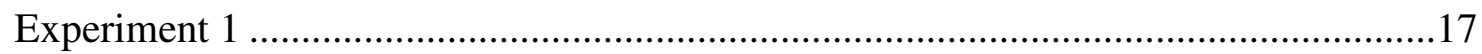

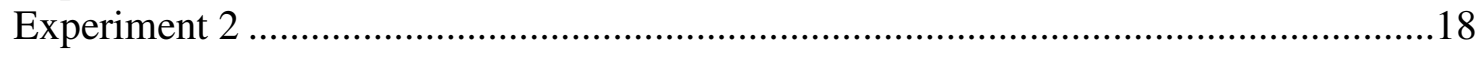

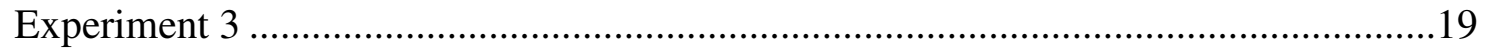

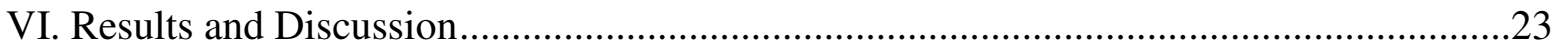

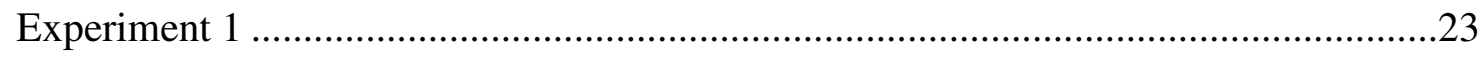

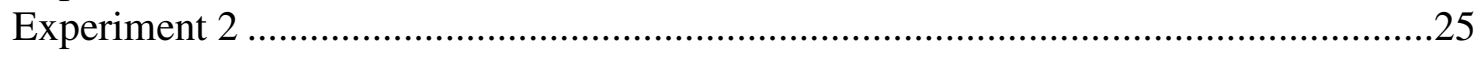

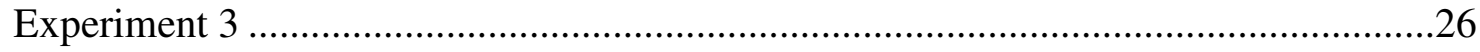

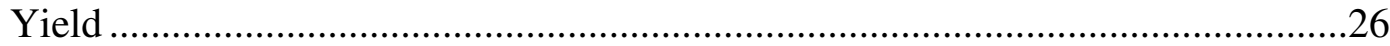

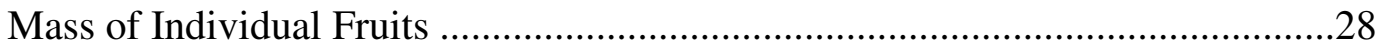

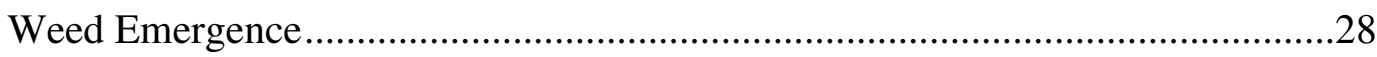

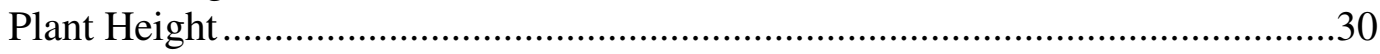

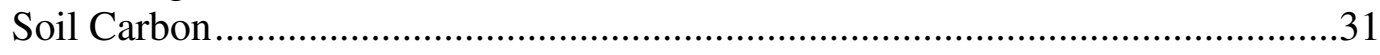

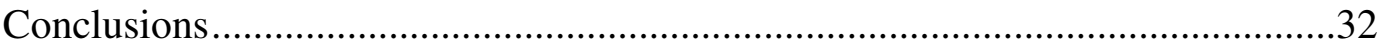

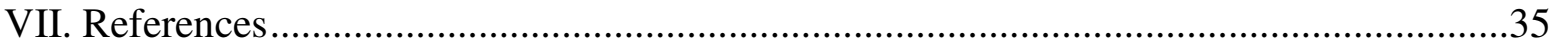




\section{List of Tables}

Table 1. Grain species characteristics as winter cover crop ................................................25 


\section{List of Figures}

Fig. 1. Effect of tillage on emergence of Malva spp. and other weeds .............................23

Fig. 2. Effect of tillage on cumulative yields of 'Lantern' bell peppers ..............................26

Fig. 3. Effect of tillage on individual fruit mass of 'Lantern' bell peppers..........................28

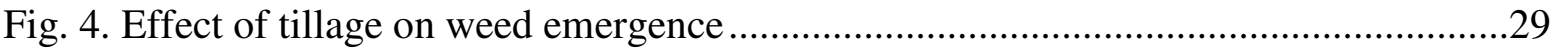

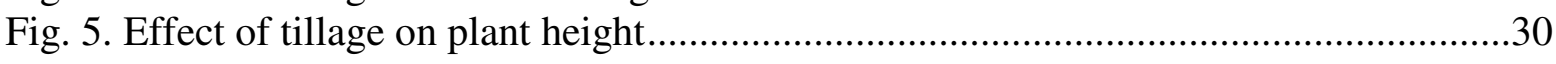

Fig. 6. Change in percentage of total soil carbon before and after treatments .......................31 


\section{Appendices}

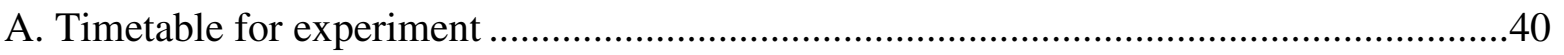

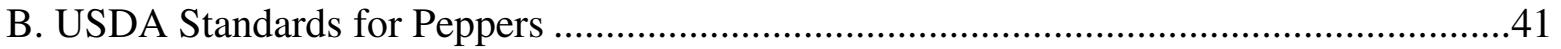

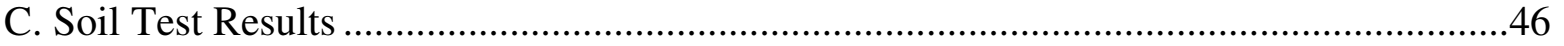




\section{Introduction}

Approximately 75 billion tons of fertile soil are lost from world agricultural systems each year, with much less erosion occurring in natural ecosystems (Myers, 1993).

Farmers have begun to respond to serious soil losses with new conservation tillage technologies that decrease the typical number of soil disturbances experienced in an agricultural system, as well as maintaining more of the soil cover for longer periods of time. In the U.S. during the 1990's, no-till farming acreage rose from 16 million to 52 million acres, an increase of $225 \%$ (Fawcett and Caruana, 2001). However, the majority of this farm land had been in conventional corn and soybeans, which relied on synthetic pesticides and fertilizers, as well as genetically-engineered crops (Brady and Weil, 2004).

Organic farmers have begun to express an interest in adopting no-till systems to avoid the potentially negative consequences of soil disturbance. Organic farming has traditionally relied heavily on tillage to create seedbeds, bury crop residues, and control weeds. Exposed soil is not only vulnerable to wind and water erosion, but also soil nutrient leaching, reduced biological diversity, and loss of organic matter (Brady and Weil, 2004).

Researchers and organic growers have been developing alternatives to some of the tillage required for crop management. One system involves the growing of a dense cover crop, killing the cover crop, and then planting or transplanting into the cover crop residue (Kuepper, 2001). This system is sometimes referred to as the "killed-cover-crop mulch system" or "in-situ mulch system." However, much of this research has been carried out on the east coast of the United States (Creamer et al., 1995; Abdul-Baki and Teasdale, 
1993) in climates very different from the central coast of California, which is characterized by hot/dry summers and mild/wet winters.

In response to this gap in the research, organic no-till vegetable production was studied from November 2007 - November 2009 at the California Polytechnic State University Organic Farm (CPOF) at San Luis Obispo. The effect of tillage type on weed suppression was studied in 2007-2008. A corollary cover crop trial was performed in 2007-2008 to help determine the best grass cover crop for a killed-mulch system. In 2008-2009, a study with a larger scope was performed to determine the effect of tillage type on bell pepper yield, weed suppression, plant vigor, and soil health.

\section{Importance of the Project}

This research will help determine the usefulness of no-till vegetable production for the Cal Poly Organic Farm at its different scales of production. By extension, these studies will benefit small- to medium-sized growers on the central coast of California by adding to the limited body of knowledge on such techniques. Adoption of the killedcover-crop mulch system for vegetable crops may decrease the time spent weeding, fuel for tractor use, erosion potential and release of $\mathrm{CO}_{2}$ into the atmosphere, while at the same time improving certain soil properties related to crop growth (e.g., increased organic matter), increasing produce yields comparable to standard tillage practices, and increasing profits. 


\section{General Approach}

This research assessed the usefulness of the killed-cover-crop mulch system for vegetable crops at the Cal Poly Organic Farm. It consisted of empirical studies over two growing seasons conducted mainly on-farm, though some data was gathered in a laboratory. 


\section{Literature Review}

Organic farming relies heavily on tillage to create seedbeds, bury crop residues, and control weeds. The soil is left bare as a result. Exposed soil is vulnerable to erosion, nutrient leaching, reduced biological diversity, and loss of organic matter (Brady and Weil, 2004). Furthermore, tillage is energy intensive and a contributor to $\mathrm{CO}_{2}$ in the atmosphere. Production systems are needed which can offer organic growers alternatives to the frequent tillage done for crop management. No-tillage systems ("no-till") in which crop residues are maintained on the soil surface may mitigate some of the negative effects of the soil being left bare (Brady and Weil, 2004).

Between 1990 and 2000, no-till farming acreage rose in the U.S. from 16 million to 52 million acres, an increase of $225 \%$ (Fawcett and Caruana, 2001). The majority of notill production land is in conventional corn and soybeans, which relies on chemical pesticides and fertilizer, and, increasingly, genetically engineered crops (Brady and Weil, 2004). Organic farmers have expressed an interest in no-till systems involving a highresidue, killed cover-crop as an in-situ mulch, instead of incorporating cover crops as green manure (Morse, 2006). Many researchers have begun investigating organic no-till production systems utilizing such techniques (Morse, 2006; Creamer et al., 1995; AbdulBaki and Teasdale, 1993). However, this research has largely taken place on the east coast of the United States in climates very different from the central coast of California. Recent research on no-till farming for the west coast of the United States has largely been focused on field crops and non-fresh market vegetables (Mitchell et al., 2008; Veenstra, 2006). 


\section{Benefits of Cover Crops}

Cover crops are grown to protect the soil surface, especially during periods when cash crops cannot be grown. Cover crops can include legumes, grains or a mixture of the two. They can be turned under by tillage as a green manure or killed and left on the surface as a mulch. Cover crops may have several benefits, regardless of their management, including reducing soil erosion, reducing leaching losses of soil nutrients, fixing atmospheric nitrogen, improving soil organic matter content (thereby increasing water infiltration rates, water holding capacity and cation exchange capacity) (Brady and Weil, 2004), and reducing weed competition (Liebman and Staver, 2001).

Legume cover crops can provide substantial $\mathrm{N}$ to the soil. A hairy vetch cover crop mulch produced $112 \mathrm{lbs}$ N/ac and reduced the amount of nitrogen fertilizer needed for optimal yield of tomatoes by $90 \mathrm{lbs}$ N/ac (Abdul-Baki et al., 1997). Generally, $40 \%$ of the nitrogen produced by the cover crop becomes available for other plants to use the first year after the cover crop is killed and left on the soil surface (Sullivan et al., 1991).

About $60 \%$ is available in the same time frame when the cover crop is incorporated into the soil.

A fast-growing, dense cover crop can help prevent weed seed formation during the time that the cover crop is growing. Therefore, cover crops can help form part of a weed management plan for growers. The slow growth of some legume mixes and the emergence of weeds can sometimes be managed with higher application rates of the cover crop (Brennan and Smith, 2005). However, little research has been carried out on the West Coast to optimize cover crops for use with organic no-till production systems. 


\section{Killed-Cover-Crop Mulch Vegetable Production Systems}

Systems have been investigated focused on growing a dense cover crop to full bloom or early seed formation, killing it, and planting or transplanting vegetable propagules into the residue. The biological characteristics of the cover crop must be taken into consideration to avoid cover crop re-growth (Sullivan et al., 2001) which can negatively interfere with cash crop growth. These systems have not yet been used with very fineseeded crops (e.g., carrots).

In conventional no-till systems, herbicides are the primary means for killing the cover crops. Both mechanical technologies and weather stress are being employed to kill cover crops in organic systems, and the mechanical systems include mowing, undercutting, rolling, and crimping (Kuepper, 2001).

Researchers have investigated various methods for mechanically killing cover crops. In a study in North Carolina focused on summer cover crops, mowing was generally more effective than undercutting at killing broad-leaved cover crops (e.g., buckwheat, fava beans, tansy-leaf) (Creamer, 1995). Undercutting was more effective than mowing at killing grasses (e.g., sudangrass, rye, oats). Generally, mowing and undercutting are more effective than rolling at killing both broad-leaved and grass cover crops (Kuepper, 2001). Rolling, however, can be achieved at greater speeds than mowing. Flail mowing chops the biomass very finely, which leads to faster breakdown and a shorter period of soil coverage. Sickle-bar mowers cut the cover crops close to the soil and lay the mulch uniformly; however, the sickle bars are easily jammed with plant residue.

In one study on the east coast, winter grasses and hairy vetch (Viciad villosa Roth.) were evaluated for their usefulness as a killed-cover-crop mulch for the home garden, 
where incorporation of cover crop material can be quite difficult with hand tools (Schonbeck et al., 1995). The grasses included rye (Secale cereal), ryegrass (Lolium perenne), field brome (Bromus arvensis), Blando brome (Bromus mollis L.), annual bluegrass (Pоа аппиа), triticale (Triticatum x Secale), and early varieties of winter wheat (Tricticum aestivum L.). The re-growth of rye could be controlled by clipping it quite close to the ground after it had begun to shed pollen in late May, whereas ryegrass, field brome, Blando brome, and annual bluegrass all re-grew. Triticale and the early winter wheats all shed pollen later than the rye, indicating that they probably could not be mowkilled as early in a growing season.

Farm equipment has been designed specifically to function with a no-till vegetable system. Hand-transplanting is the method that is commonly employed by researchers, though much technology has been developed to aid organic no-till crop management. A subsurface tiller-transplanter, which loosens a 2-inch wide by 6-8inch deep slot in the soil, and sets vegetable starts or seed potatoes, has been developed (Morse and Schonbeck, 2007). Other no-till planting aids have been developed that usually consist of a coulter and a heavy shank that leave a narrow swath of prepared soil for vegetable starts or seed (Kuepper, 2001).

Most killed mulches do not provide thorough, long-season weed control without some additional effort (Kuepper, 2001). Research has shown no-till systems begin to favor perennial weed species over time (Teasdale and Abdul-Baki, 1998). Many systems have been able to achieve no-till from the time the cover crop is sown, through growing the cash crop, until it is time to prepare the ground for another annual cover crop 
(effectively, 1 year). Some have referred to this system as "rotational tilling" (Morse and Schonbeck, 2007).

\section{Weed suppression in Organic No-till Vegetable Production}

Traditionally, organic farmers incorporate cover-crop residues as green manure, which leaves the soil surface uncovered and vulnerable to erosion and the proliferation of weeds. Weed control is considered to be the greatest problem facing organic growers (Walz, 1999). Hand-weeding or mechanical cultivation are typically the methods used to remove or kill the weeds. Both methods can be expensive, time consuming, and the latter can degrade soil quality (Kuepper, 2001).

In a 3-year study on organic no-till potato production, weed growth was generally held below yield-limiting levels without applying herbicides, indicating the cover-crop production and management system employed in the study could be used to produce organic potatoes (Morse, 2006). Potato seed pieces were no-till planted into a living rye cover crop. The cover crop was then killed with a flail mower just before the potato sprouts emerged through the soil surface. Weed suppression did not correlate strongly with cover crop type (i.e., rye vs. rye/hairy vetch), but did correlate strongly with seasonal rainfall.

Species of cover crop can also affect weed suppression potential. Weed biomass was measured in a no-till sweet corn study using a vetch cover crop as a mulch, a cover crop mix of rye and vetch as a mulch, and bare soil (Carrera et al., 2004). The vetch treatment resulted in less weed biomass than the cover crop mixture. The cover crop mixture, in turn, resulted in less weed biomass than bare soil. 
The total time spent weeding can be drastically reduced in a no-till system. A mowkilled mulch of hairy vetch and rye was studied against a more standard organic option in which the same cover crops were tilled into the soil in advance of planting tomatoes (Schonbeck et al., 1995). The overall time spent in weed management on the killedmulch plots was about three-fourths that spent on the tilled plot, which could result in a cost savings for an organic grower.

In a 3-year study on the effect of cover crops on weed populations in lettuce, a summer cover crop mulch treatment resulted in fewer weed species mid- and early season compared to a summer fallow treatment (Ngouajio et al., 2003). Weed density was the least in a cowpea mulch compared to treatments in which the cowpeas were incorporated, sudangrass was incorporated, and or the soil was allowed to remain fallow during the summer. No-till organic vegetable production, therefore, has the potential to reduce the number of weed species and weed densities during critical growth periods for vegetable crops.

In a study at the Cal Poly Organic Farm at San Luis Obispo, California, summer annual weeds were less when a winter cover crop was mown and left of the surface as a mulch compared to when the cover crop was incorporated (Booker, 2009). It was observed that in both treatments weeds primarily emerged along the dripline.

A combination of both grains and legumes in a cover crop may produce enough biomass to suppress weeds and deliver nitrogen to a crop at a rate conducive to plant growth (Creamer, 1999). At least 3 tons per acre of aboveground biomass was essential to achieve 5-7 weeks of weed suppression on the east coast of the United States (Morse and Schonbeck, 2007). In a three-year study utilizing the winter cover crops hairy vetch 
and rye grown as either alone or in combination, it was concluded that combining the cover crops generally produced greater biomass and weed suppression (Teasdale and Abdul-Baki, 1998).

Some cover crops exhibit allelopathic effects. Rye produces chemicals that inhibit free germination and growth of a large number of broadleaf and grassy weeds (Kuepper, 2001). Lablab beans and radishes (forage and daikon varieties) have been explored for use as a killed mulch. Their residues break down quickly after being winterkilled, yet winter weed growth is delayed due to an allelopathic effect, leaving a nearly clean seedbed for spring planting (Morse and Schonbeck, 2007). Allelopathic effects can, however, extend to cash crops. Researchers explored the possibility of allelopathic damage to tomato, broccoli and lettuce crops transplanted into a mow-killed sorghumsudan mulch (Mitchell, personal communication, 2009). All three crops suffered allelopathic damage.

\section{Yield in Organic No-till Production Systems}

Organic no-till production systems have the potential to yield as well as tilled systems. In a two-year study at the Cal Poly Organic Farm (San Luis Obispo, CA) there was no difference in yield between organic tomatoes grown with or without tillage following a grain and legume cover crop (Booker, 2009). Although in both years there was no difference in yields, the yields for all plots were below California state averages (Le Strange et al, 2000). In a 4-year study in Virginia, using high-residue cover crop mulches with organic no-till potato production, yields of marketable creamer (2002) and table-stock (2003-2004) potatoes were equal or higher in no-till with rye+hairy vetch and 
no-till with barley+hairy vetch plots than in no-till with rye or conventional till plots (Morse, 2006). The same study found that in 2004, organic tuber yields in no-till plots were similar to the Virginia state average for non-organic commercially grown conventional till potatoes.

No-till plots do not always yield as well as tilled plots. In one study in which organic tomatoes were grown in a mow-killed rye and vetch cover crop, plots produced more fruit early in the season, but the yield differences became less between tilled and no-till treatments as the season continued (Schonbeck et al., 1995). No-till plots may have had cooler soil temperatures that led to slower early tomato growth. The difference in total yield of tomatoes between the mulched and tilled plots was also not considered significant.

In a study on organic no-till bell pepper production, plants grown no-till with bare soil and no-till in a hairy vetch mulch yielded less at one location than plants grown using tillage and a black polyethylene mulch (Abdul-Baki et al., 1999). Additionally, the black polyethylene treatment advanced fruit maturity by 20 days in one location, while only 4 days at another.

\section{Soil Organic Carbon in No-till Vegetable Production}

Conservation of soil carbon content is needed for sustaining soil quality, productivity, and environmental quality (Brady and Weil, 2004). Tillage is generally considered to reduce soil organic $\mathrm{C}$ by increasing residue incorporation, disrupting soil aggregates, and increasing aeration. In a tilled system the oxidized soil carbon $\left(\mathrm{CO}_{2}\right)$, a greenhouse gas, is sent back into the atmosphere contributing to anthropogenic climate 
change. Changes in soil organic $\mathrm{C}$ can occur slowly because of their large pool size and tendency for spatial variability (Sainju et al., 2001).

No-till vegetable production may increase soil organic carbon. A 3-year experiment was conducted in Central Georgia examining the influence of tillage practices (i.e., notill, chisel plowing, and moldboard plowing), cover crops (hairy vetch vs. winter weeds), and $\mathrm{N}$ fertilization rates on soil organic $\mathrm{C}$ and tomato yield. Soil organic $\mathrm{C}$ was greater in plots subjected to no-till with vetch than in plots either chisel or moldboard plowed with vetch or weeds at 0- to 8-in soil depth (Sainju et al., 2001).

Tillage does not always influence soil organic $\mathrm{C}$ as much as cover cropping. A 4year study was conducted on the effect of conservation tillage on the physical and chemical properties of the soil used for a cotton-tomato rotation in the San Joaquin Valley of California (Veenstra et al., 2006). In this study, the addition of cover crop residues increased soil carbon regardless of tillage practice. In a standard tillage + cover crop treatment, total carbon increased at both the 0-6 inch soil depth and 6-12 inch soil depth. A conservation tillage + cover crop treatment only increased the total $\mathrm{C}$ in the soil to a 0-6 inch depth. The total carbon increase averaged across the cover crop treatments over 4 years was 4,200 pounds per acre. The results of this research challenge other research suggesting the difficulty of $\mathrm{C}$ accumulation in conservation tillage systems in semi-arid environments (e.g., Potter et al., 1998).

Some studies suggest that there is no actual difference in total soil C amongst tillage treatments when the entire soil profile is taken into consideration. Soil carbon between plowed fields and fields managed with no-till practices was compared for up to 30 years on working farms in 3 states on the east coast of the United States (Blanco-Canqui et al., 
2008). In many sites there was no difference between no-till and plowed fields in soil carbon accumulation when measuring carbon from the entire soil profile (depths below 12 inches). Three of the 11 sites had greater soil carbon accumulation in the plowed fields than in the no-till fields.

There is a notable paucity of research on soil carbon in strictly organic no-till or conservation till systems. Organic systems may have more soil fauna (e.g., beetles and worms) to mix plant residue deeper into the soil strata. It may take as long as 4 years for the population of soil fauna to regenerate after decades of intensive tillage (Veenstra et al., 2006).

Rotational tillage, which is typically employed in organic no-till vegetable systems to bury crop residue, weeds and prepare ground for a cover crop, has the potential to conserve more soil organic carbon than continuous no-till. Greater gains of soil organic carbon at subsurface depths were found when no-till was followed by a short period of conventional till and then returned to no-till compared to no-till for 28 years and conventional till followed by 11 years of perennial grasses (Purakayastha et al., 2008). The researchers considered this as evidence that physical movement of soil organic carbon through tillage to subsurface depths could be a mechanism for increasing total soil organic carbon for systems under mainly no-till management.

\section{Conclusions}

Cover crops benefit organic growers regardless of whether they are incorporated. Organic farmers are seeking new ways to protect against the negative effects of bare soils through conservation and no-till technologies. One such system utilizes a killed-cover- 
crop mulch that involves growing a dense cover crop to full bloom or early seed formation, killing it, and planting or transplanting vegetable propagules into the residue. Leaving cover crop residues on the soil surface may also suppress weeds long enough for a cash crop to be grown without any additional weeding, cultivations or herbicides. Organic no-till vegetable production systems may also yield as well as conventional till systems, and accumulate soil organic carbon. 


\section{Objectives and Hypotheses}

\section{Objective}

- The objective is to determine whether organic no-till vegetable production is useful for the Cal Poly Organic Farm's various scales of production.

\section{Hypotheses}

- There is a difference in the effect of tillage type on zucchini yield, and weed suppression.

- There is a difference in the effect of grain species in a cover crop on cover crop biomass.

- There is a difference in the effect of tillage type on bell pepper yield, weed suppression, total soil carbon, and plant vigor. 


\section{Assumptions}

The following was assumed:

- Variation due to environmental gradients (e.g., soil variation, climatic variation) is accounted for with randomization.

- Prior use of the plots had no influence on current study.

- A buffer zone preserved the integrity of the treatments.

- Differences in treatment effects could be measured using relatively small plot sizes and in one growing season. 


\section{Materials and Methods}

The objective of the research was to determine whether organic no-till vegetable production could be useful for the various scales of production used by the Cal Poly

Organic Farm. Three experiments were conducted over two growing seasons to be able to refine research methods. Experiment 1 sought to test the effect of tillage type on zucchini yield and weed suppression. Building on the challenges of cover crop re-growth in experiment 1 in no-till plots, experiment 2 sought to test new cover crop species for biomass and re-growth. Experiment 3, the largest in scope, sought to test the effect of tillage type on bell pepper yield, weed suppression, total soil carbon, and plant vigor.

\section{Experiment 1}

The first experiment was conducted in 2007-2008 on commercial-scale certified organic farmland at California Polytechnic State University, San Luis Obispo. Field soil at the site was a silty clay loam, $\mathrm{pH}$ 7.5. The site had not been planted to zucchini (Cucurbita pepo) or any Cucurbitaceous crop for at least 2 years. Two treatments were compared, tilled and no-till ( $\mathrm{T}$ and NT, respectively). The experiment did not achieve its full intended scope due to crop failure in the NT plots, which may have been due to an insect pest interaction (see Results and Discussion).

The experimental design was a randomized complete block design with 11 replications. Each treatment plot consisted of two 3.33' x 30' beds.

Beds for the cover crop were erected in mid-October 2007 and all plots were seeded on Novermber 1, 2007 at a rate of 120lbs/acre with an "Organic Soil Builder Mix" cover crop consisting of $40 \%$ bell beans (Vicia fabia), $20 \%$ Magnus winter peas (Pisum 
arvense), $15 \%$ Lana vetch (Vicia dasycarpa), $15 \%$ purple vetch (Vicia autopupurea), and $10 \%$ 'Juan' triticale (Triticum X Secale), by volume (Peaceful Valley Farm Supply, Grass Valley, CA). The cover crop was irrigated once with overhead sprinklers and no fertilizer was added. Immediately before mowing, random samples were taken from 1$\mathrm{m}^{2}$ areas of cover crop outside the experimental plots, dried overnight at $158^{\circ} \mathrm{F}$ in a forced-air oven, and weighed to determine biomass. Tilled plots were mown with a high speed rotary mower, disk-ploughed twice, and beds were shaped. No-till plots were mown with a sickle- mower that cut the cover crop down at 2 inches above the bed surface, creating a 6-inch thick mulch residue on the bed tops. The 'Juan' triticale continued to re-grow in the NT plots after being mown.

Seedlings of organic 'Ambassador' zucchini that had been started in a greenhouse in 128-cell flats were obtained from a commercial source. The seedlings had been maintained for 3 weeks in a greenhouse and hardened for 1 week. Each treatment plot contained 1 bed that had a single row of zucchini that was hand-transplanted at an in-row spacing of 18 in. Each bed was irrigated with one surface drip line placed next to the row of plants with the emitters facing up.

All weeds were counted and removed by hand on June 15, 2008, June 29, 2008, and July 13, 2008.

Statistical analysis was conducted using Minitab ver. 12 (Minitab Inc., State College, PA). The existence of significant differences $(\alpha=0.05)$ was determined through ANOVA. 


\section{Experiment 2}

The second experiment was conducted in 2007-2008 on commercial-scale certified organic farmland at California Polytechnic State University, San Luis Obispo, to compare different cover crops for use in organic no-till vegetable production. The field had not been farmed for many years and weed and animal pests were a problem. Four cover crop species were chosen as treatments applications, beardless barley (Hordeum vulgare), 'Montezuma' red oats (Avena sativa), cereal rye (Secale cereale), and 'Juan' triticale (Triticum X Secale).

The experimental design was a completely randomized design with 24 plots. Each plot consisted of two 3.33' x 30' beds.

Beds for the cover crop were listed in mid-October 2007 and experimental plots were seeded on November 3, 2008 with one of the cover crop treatments at a rate of 100lbs/acre. Seed and seeding rates were obtained from Peaceful Valley Farm Supply, Grass Valley, CA. All cover crops were irrigated once with overhead sprinklers and no fertilizer was added. Only 'Montezuma' red oats and 'Juan' triticale produced sufficient stands for measuring due to seeds being eaten by rodents.

When each cover crop was at approximately $50 \%$ flower, three random samples were taken from $1-\mathrm{m}^{2}$ areas from each plot, dried overnight at $158^{\circ} \mathrm{F}$ in a forced-air oven, and weighed to determine average biomass.

Statistical analysis was conducted using Minitab ver. 12 software (Minitab Inc., State College, PA). The existence of significant differences $(\alpha=0.05)$ was determined through a t-test. 


\section{Experiment 3}

The third experiment was conducted in 2008 -2009 at a market garden scale on certified organic land at the California Polytechnic University, San Luis Obispo. Field soil at the site was a loam, with a pH of 6.5. The site was sloped (15-30\%). The growing beds were terraced, roughly on the contours of the slope with grassed pathways between beds. The site had not been planted to peppers or any other Solanaceous crop the prior year. Two treatments were compared, tilled and no-till (T and NT, respectively).

The experimental design was a completely randomized design with 10 plots. Each plot consisted of a bed 3.33' x 15' in size.

All plots were seeded on December 15, 2008 with an "Organic Soil Builder Mix" cover crop consisting of $40 \%$ bell beans (Vicia fabia), $20 \%$ Magnus winter peas (Pisum arvense), $15 \%$ Lana vetch (Vicia dasycarpa), $15 \%$ purple vetch (Vicia autopupurea), and $10 \%$ Juan triticale (Triticum X Secale), by volume (Peaceful Valley Farm Supply, Grass Valley, CA), at a rate of $120 \mathrm{lbs} / \mathrm{acre}$. The cover crop was exclusively rain irrigated and received no fertilizer. Immediately before mowing, random samples were taken from $1-\mathrm{m}^{2}$ areas of cover crop outside the experimental plots, dried overnight at $158^{\circ} \mathrm{F}$ in a forced-air oven, and weighed to determine biomass. Tilled plots were mown with a selfpropelled brush mower, loosened to a depth of 12 in with a hand-fork, and roto-tilled to a depth of 8 in. No-till plots were cut down by hand with a scythe 2.5 in above the bed surface, creating a 5 in thick mulch residue on the bed tops.

Seeds of organic 'Lantern' bell peppers (Capsicum annum) were obtained from Johnny's Selected Seeds (Winslow, ME) and started in a greenhouse in 128-cell flats. The seedlings were maintained for 6 weeks in the greenhouse and hardened for 2 weeks 
before being transplanted. A single row of pepper plants was manually transplanted in each plot at an in-row spacing of 12 in. Each plot was irrigated with one surface drip line placed next to the row of plants with the emitters placed downwards. It had been observed in Experiment 1 that placing drip emitters upwards on an uneven mulch layer in NT plots resulted in a non-uniform wetting pattern. Plots were maintained at or near field capacity according to the soil-moisture-by-feel method (Miles and Brown, 2003).

A composite preplant soil nutrient availability test administered by Fruit Growers Lab (Santa Paula, CA) revealed excessive P, and optimal N and K (see Appendix C). Feather tea, gypsum and boron were injected through the drip system one week after planting, and five applications were made thereafter biweekly, adding approximately 0.10 lbs/acre N, $0.04 \mathrm{lbs} /$ acre K, $5 \mathrm{lbs} / \mathrm{acre} \mathrm{Ca}, 3.5 \mathrm{lbs} / \mathrm{acre} \mathrm{S}$, and $0.010 \mathrm{lbs} / \mathrm{acre} \mathrm{B}$ to the soil. Estimates indicated that the cover crop would have added $108 \mathrm{lbs}$ N/ac in T plots and 72 lbs N/ac in the NT plots (Sullivan, 2003). Seasonal N mineralization was assumed to be quite high due to the soil's initial $4.5 \%$ organic matter content (Gaskell, 2007).

Seven harvests were made from plots 1, 2, 3, 8, 9, and 10 (plots 4, 5, 6, and 7 had crop failure due to rodent damage). At each harvest, all marketable fruits (USDA grade 2 or above; see Appendix B) from the middle 12 plants of each treatment plot were weighed and the number of bell peppers counted to determine fruit weight per plot.

All weeds within the plots were counted and removed by hand four times at biweekly intervals after planting until canopy closure was achieved.

All pepper plants were measured for height (in.) when blooms were first present on $100 \%$ of the plants, and at the end of harvest. 
The change in percentage of total soil carbon before and after the application of the treatments to the plots (December 14, 2008 and December 1, 2009, respectively) was measured using an Elementar Vario MAX CNS Element Analyzer (Hanau, Germany) (Sparks, 1996). Three samples taken from each plot (60 total).

Statistical analysis was conducted using Minitab ver. 12 software (Minitab Inc., State College, PA). The existence of significant differences $(\alpha=0.05)$ was determined through a t-test. Levene's test of equal variances was used to determine whether the variances could be assumed to be equal. 


\section{Results and Discussion}

\section{Experiment 1}

Tilled plots had a higher cumulative weed count of 452.8 plants per plot than NT which had a cumulative weed count of only 91.2 plants per plot $(\mathrm{p}<0.01)$. There was also more Malva (Malva spp.) in T plots ( $\mathrm{p}<0.01)$. Tilled plots had a cumulative 207 Malva plants per plot compared to the NT plots which had only a cumulative total of 34 plants per plot.

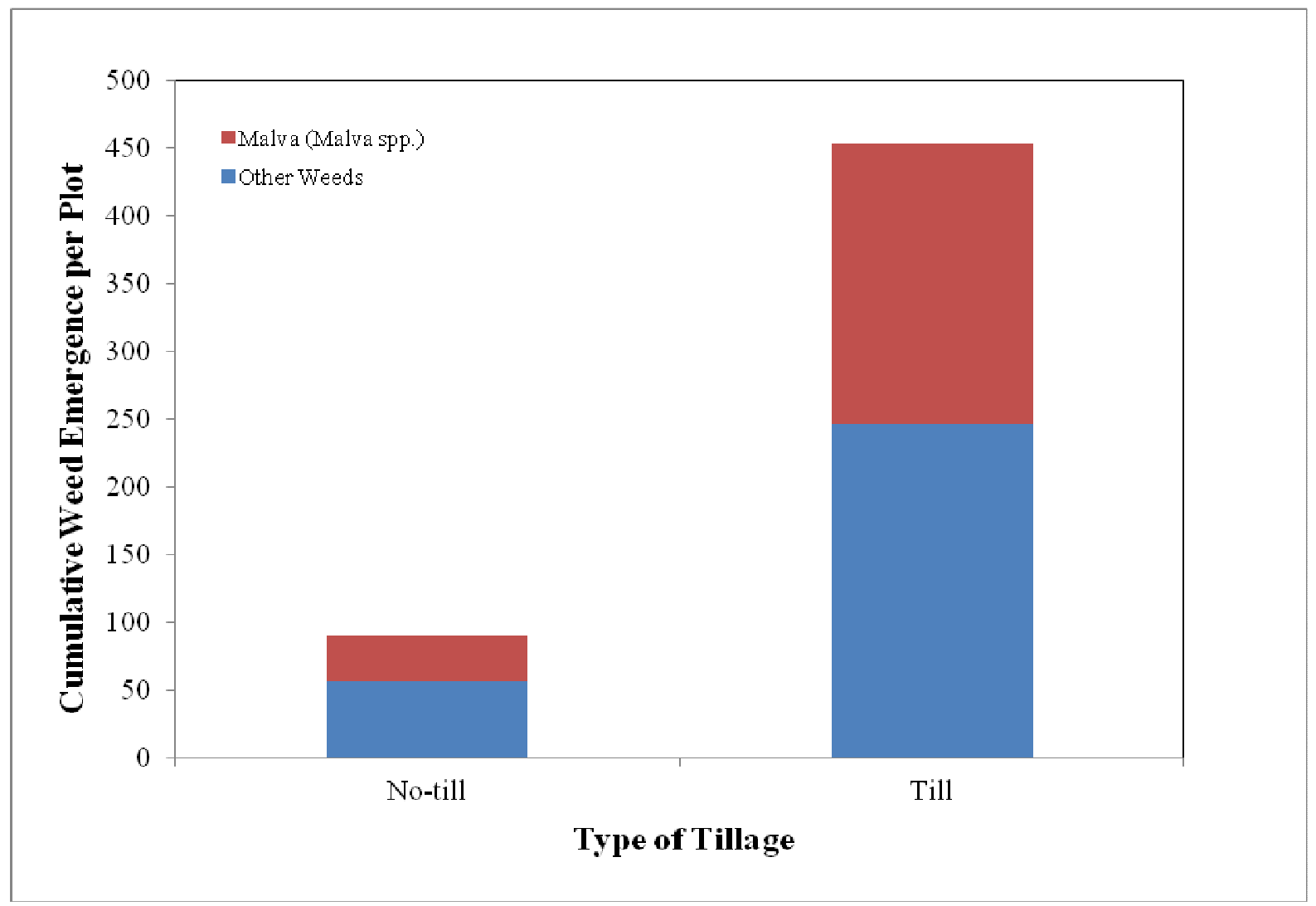

Fig. 1. Effect of tillage on emergence of Malva spp. and other weeds.

The mulch layer created in NT plots may have prevented sunlight from reaching the soil reducing the germination of some weed seeds. Additionally, less weed seeds may have been brought nearer to the surface due to the lack of tillage. This research confirms 
previous research at the Cal Poly Organic Farm that a killed cover crop mulch can reduce weed emergence (Booker, 2009).

Less weeds were found in NT plots than T plots with cover crop biomasses below the no-till guidelines suggested for the east coast (Morse and Schonbeck, 2007). The cover crop from experiment 1 had an aboveground biomass of 2.29 tons/acre and the cover crop for experiment 3 had 2.76 tons/acre compared to the guideline of 3 tons/acre for weed control in no-till systems on the east coast. This suggests, not surprisingly, that different no-till guidelines may need to be created for various California climates. The hot dry summers of the central coast of California may permit the cover crop mulch to persist much longer on the soil surface. Drip irrigation tends to only germinate weeds in a band adjacent to the drip tape. This would also affect the rate at which mineral nutrition from the cover crop biomass becomes available for subsequent crops. It may be possible for California growers to kill a cover crop at an earlier stage of growth, then plant into the mulch earlier and still have enough biomass in the mulch to achieve weed suppression. Many non-grass cover crops may generate enough biomass and be easier to kill. Planting earlier may be particularly important for California growers looking to take advantage of early markets for their crops.

Although no specific cause for the zucchini crop failure in the NT plots was determined, it was observed that there was more cucumber beetle (Diabratica spp.) activity in NT plots than T plots. Future studies might want to measure pest interactions. 


\section{Experiment 2}

'Juan' triticale produced an average dry aboveground biomass of 3.91 tons/acre. 'Montezuma' red oats produced an average dry aboveground biomass of 3.34 tons/acre. There was no significant difference between treatments in the amount of aboveground biomass measured (Table 1). The 'Juan' triticale took 12 days longer to reach anthesis than 'Montezuma' red oats.

Table 1. Grass species characteristics as winter cover crop.

\begin{tabular}{|c|c|c|c|}
\hline Cultivar & Days to Anthesis & $\begin{array}{c}\text { Dry Aboveground } \\
\text { Biomass (tons/acre) }\end{array}$ & Re-growth \\
\hline 'Juan' Triticale & 122 & 3.91 & More \\
\hline $\begin{array}{c}\text { 'Montezuma' Red } \\
\text { Oats }\end{array}$ & 110 & 3.34 & Less \\
\hline
\end{tabular}

Although no difference was found between these two cover crops in the amount of biomass produce, it is likely that further studies involving a range of cover crops would find that some species produce more biomass than others. 'Montezuma' red oats were easier to kill than 'Juan' triticale. A grower could potentially optimize a cover crop to suit his subsequent no-till cash crop. For example, if earliness of the cash crop is most important to a grower, he would be advised to choose a cover crop species that could be killed earlier in the season. Indeed, a more comprehensive study of cover crops for CA climates with an emphasis on suitability for no-till systems is imperative. 


\section{Experiment 3}

\section{Yield}

Cumulative yield of NT plots was less $(\mathrm{P}<0.05)$ than T plots (Fig. 2). Both treatments yielded above the USDA national average of $18.8 \mathrm{lbs} / 100 \mathrm{sq} \mathrm{ft}$ (Jeavons, 1991). Tilled plots yielded $50.6 \mathrm{lbs} / 100 \mathrm{sq} \mathrm{ft}$ and NT $19.96 \mathrm{lbs} / 100 \mathrm{sq} \mathrm{ft}$. The fact that USDA grade 2 and above peppers were harvested in the study, however, may have inflated the yields compared to data that only reported higher grades.

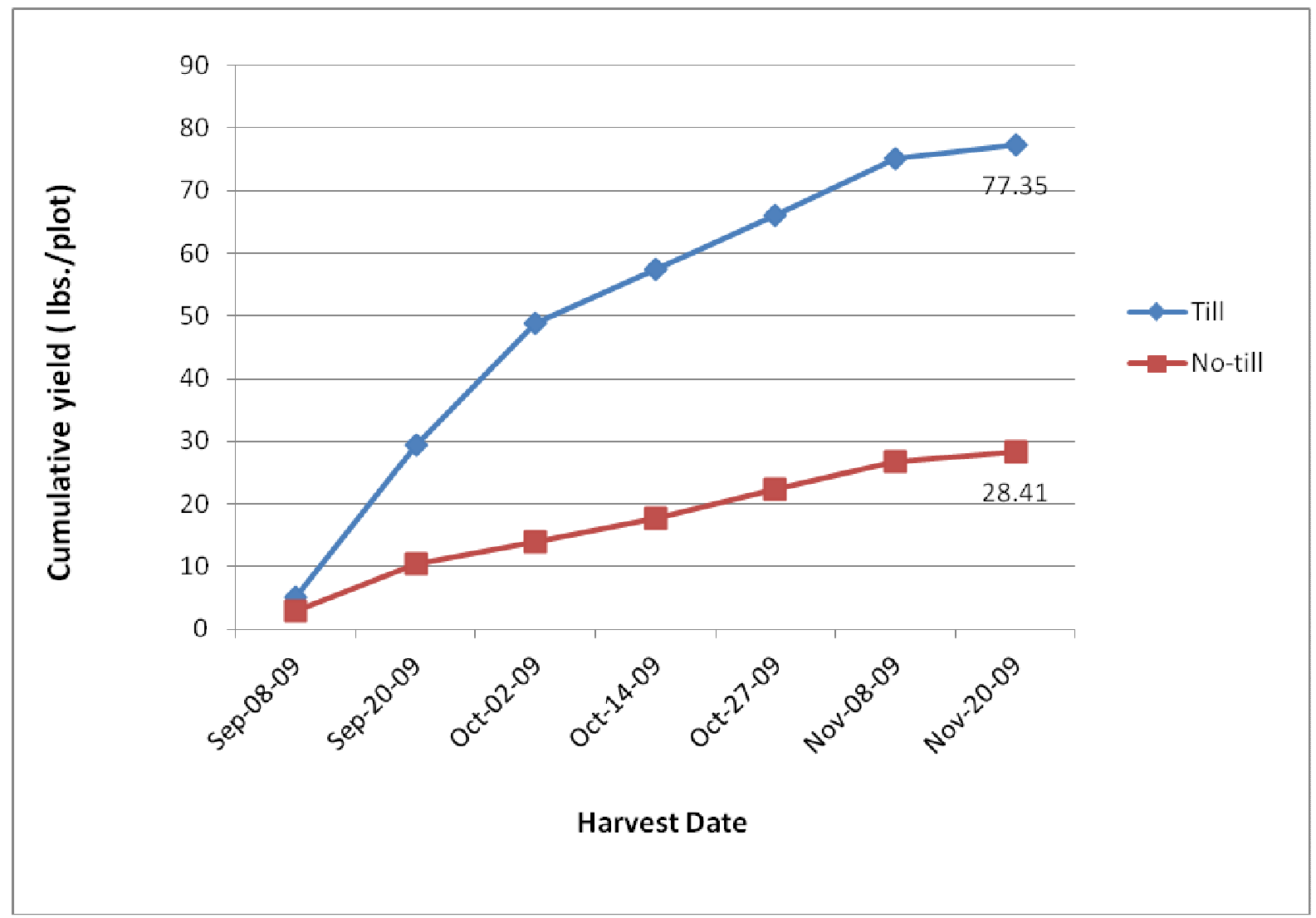

Figure 2. Effect of tillage on cumulative yields of 'Lantern' bell peppers.

A number of researchers have, similarly, found diminished yields with no-till compared to typical cover crop incorporation (e.g., Sainju et al., 2001; Schonbeck et al, 
1995). There are a number of possible explanations. Although a composite pre-plant soil test was performed for all plots, there could have been actual differences in available nutrients between treatments prior to planting and through the growth phase of the bell peppers. In particular, more $\mathrm{N}$ from the cover crop would have been available in the $\mathrm{T}$ plots (Sullivan, et al. 2003) than in NT plots. However, other than slower growth rate relative to $\mathrm{T}$ plots, peppers in NT plots did not show any visible signs of $\mathrm{N}$ or other mineral deficiencies. Tissue testing would prove useful to determine possible nutrient deficiencies in future studies.

Soil temperature may have been a factor in the difference in yield between treatments. Researchers have observed cooler soils in no-till systems where a thick mulch layer is maintained (Schonbeck et al., 1995). The cooler soil temperatures may be less than optimal for certain crops. Studies in arid cool regions have showed that a modification in the no-till system, in which residues over a narrow band (3-in-wide) are pushed aside, eliminated much of the temperature depression from standard no-till while at the same time keeping most the soil covered (Arshad and Azooz, 1996). This study would have benefited from including soil temperature measurements. In coastal districts in CA, growers sometimes utilize plasticulture in part to heat the soil and promote earliness (Hartz et al., 2008). Such approaches need to be compared to no-till systems in future studies.

Yield may also have been affected by differences in soil structure between the treatments. It is possible that an incomplete amelioration of compacted soil over the winter and from previous crop management may have reduced root growth, thereby decreasing yield and nutrient uptake in NT plots compared to T plots. Compacted soil is 
sometimes seen, particularly the $1^{\text {st }}$ year, in the transition from a tilled to no-till system (Sainju, et al. 2001).

\section{Mass of Individual Fruits}

Tilled plots had a higher average fruit mass $(\mathrm{P}<0.05)$ than NT plots (Fig. 3).

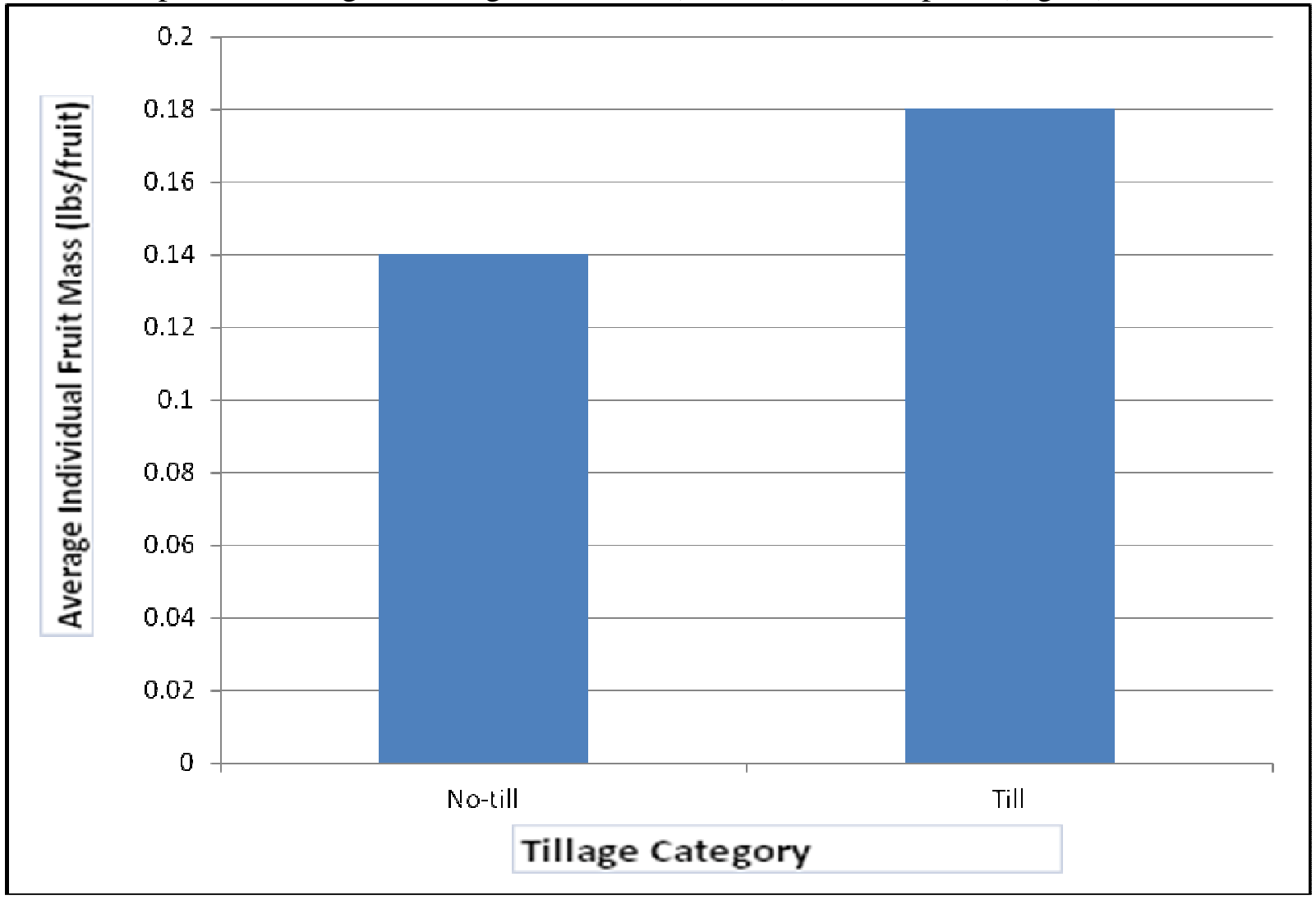

Fig. 3. Effect of tillage on individual fruit mass of 'Lantern' bell peppers.

Similar factors (i.e., variations in soil nutrients, soil temperature, and soil compaction) may account for the difference between treatments in average fruit mass. These results are contrary to those of other studies at the Cal Poly Organic Farm that showed no difference in average fruit mass with or without tillage in tomatoes (Booker, 2009). Other research in Maryland found greater fruit mass of bell peppers in a hairy vetch no- 
till treatment compared to treatments of no-till with bare soil and tillage with a blackpolyethylene mulch (Abdul-baki, 1999).

\section{Weed Emergence}

There was a difference $(\mathrm{P}<0.05)$ between treatments in cumulative weed count $($ Fig. 4). Tilled plots had an average cumulative weed count of 63.8 weeds and NT plots had an average cumulative weed count of 24.2 weeds. No-till plots had less $(\mathrm{P}<0.01)$ redroot pigweed (Amaranthus retroflexus) than $\mathrm{T}$ plots. Tilled plots had an average cumulative count of 18.4 redroot pigweed plants and NT plots had an average cumulative count of 1.6 plants.

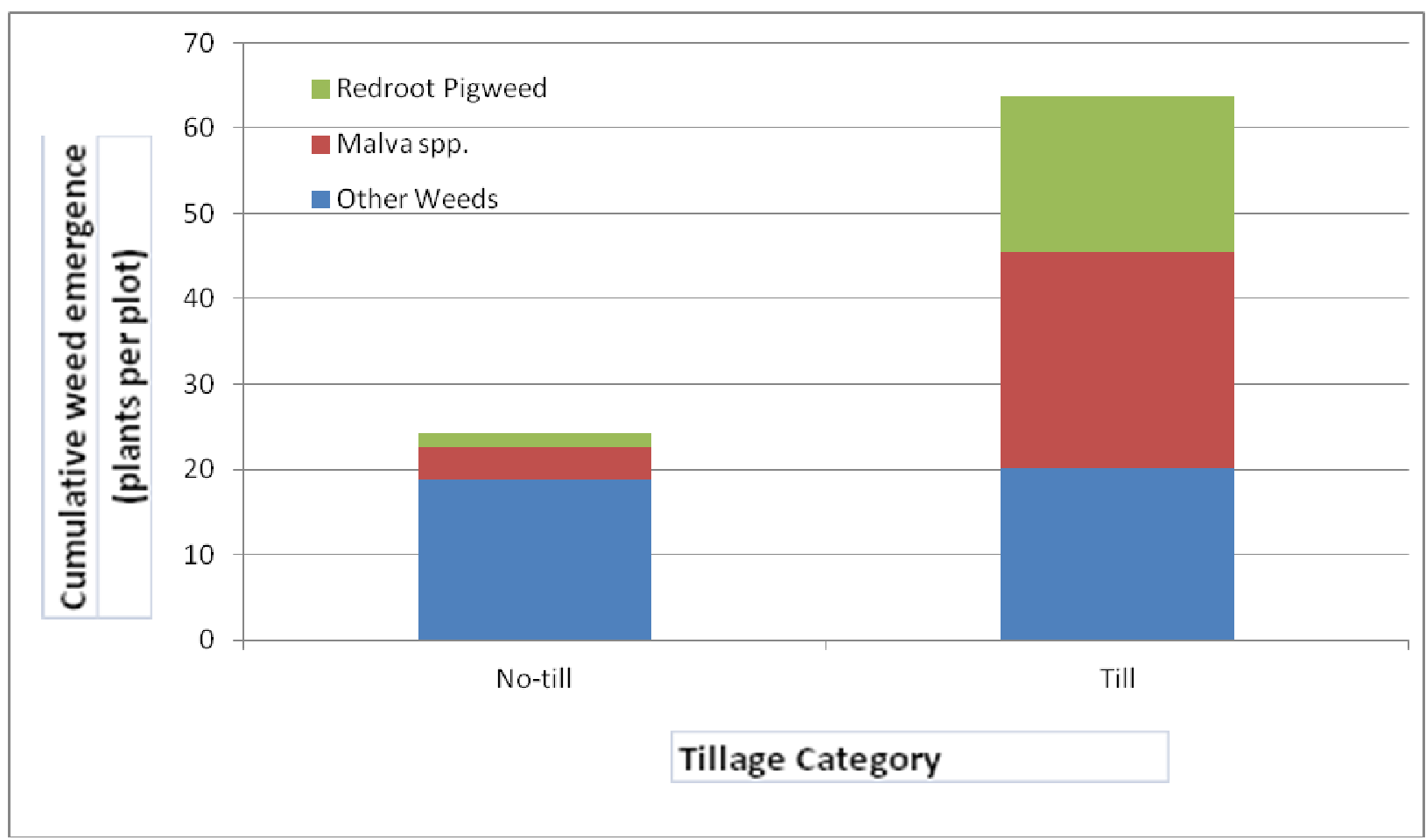

Fig. 4. Effect of tillage on weed emergence.

Tilled plots had more redroot pigweed than NT plots, confirming the finding of others that organic no-till vegetable production may be particularly useful at suppressing warm-season annual weeds (e.g., Booker, 2009; Morse and Schonbeck, 2007). Malva, on 
the other hand, germinates freely all year with the mild weather on the central coast of California. It was observed that a few malva plants had germinated and grown with the cover crop. After being mowed in preparing the NT plots, malva sometimes exhibited regrowth. These malva plants would have been included in the weed count, perhaps distorting any differences that there may have been in an effect of treatment type on suppressing the germination of malva seeds.

\section{Plant Height}

There was no difference between the treatments in the height of the pepper plants when all the plants had begun to flower at (100\% bloom) (Fig. 5). Tilled plots had an average height of 9.44 inches and NT plots 7.75 inches. There was no difference in the height of the pepper plants at the end of harvest between treatments. Tilled plots had an average height of 21.3 inches and NT plots 16.3 inches.

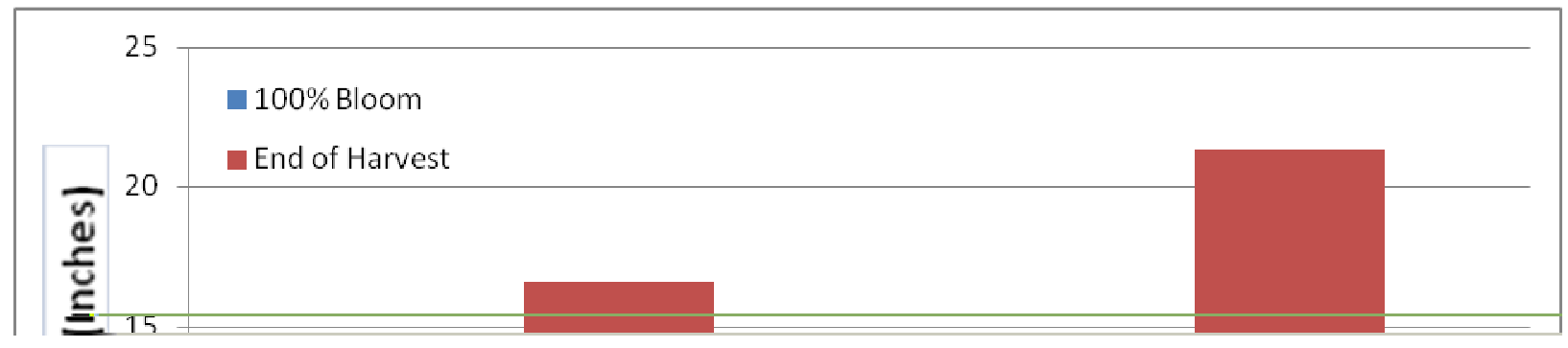


However, there was strong correlation between plant height (100\% bloom) and total cumulative yield $\left(r^{2}=.97\right)$. There may have been treatment differences early in the growing season that affected plant vigor and, subsequently, total yield. Again, it is highly recommended that soil temperature and possible pest interactions be measured in future studies.

\section{Soil Carbon}

There was no difference between the treatments in the percent change of total soil carbon before and after the application of the treatments (Fig. 6). Both treatments had an average increase in total soil carbon. Tilled plots had a mean increase of $0.17 \%$ total soil carbon and NT plots a mean increase of $0.19 \%$ total soil carbon. Changes in all plots are reported to show that both treatments had 1 plot that lost carbon.

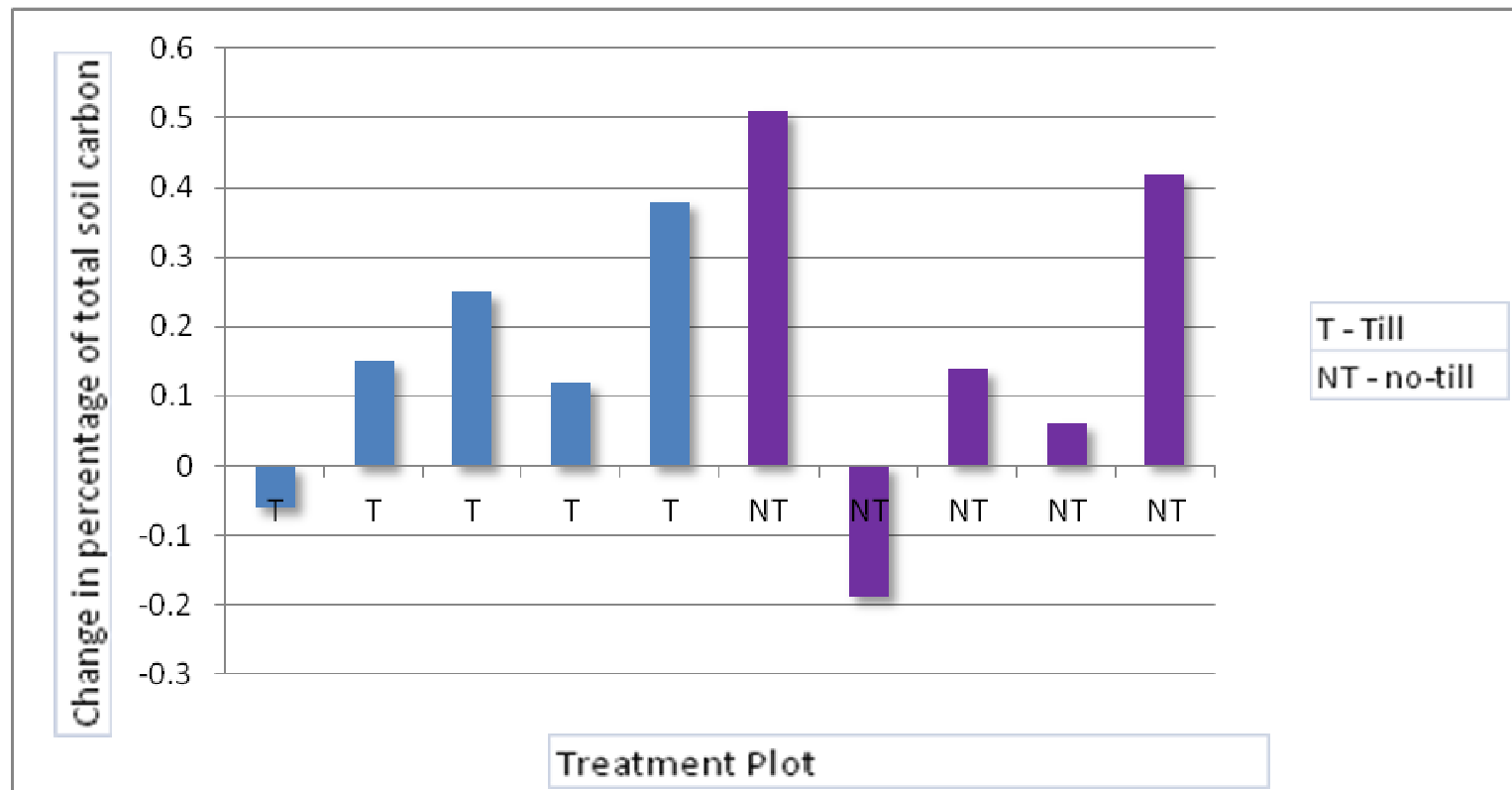

Fig. 6. Change in percentage of total soil carbon before and after treatments. 
This finding indicates the benefit of cover crops to growers regardless of tillage. Both treatments had an average increase in the percentage of total carbon in the soil before and after the treatments were applied, i.e., one cropping cycle. One assumes that $\mathrm{C}$ from the total cover crop biomass was added to the soil in $\mathrm{T}$ plots, and $\mathrm{C}$ from root biomass and some aboveground biomass was added in NT plots. However, changes could also be due to other factors such as the rhizodeposition of organic materials in soil from roots during crop growth and annual changes in soil moisture and temperature (Sainju et al., 2001). The present study would have benefited from a fallow treatment in which the soil was kept bare to see what changes occur without the additional cover crop biomass and also a treatment in which a bell pepper crop was grown without a preceding cover crop. It is possible the amount of $\mathrm{C}$ added by the incorporation of the cover crop biomass in $\mathrm{T}$ plots offset the loss of $\mathrm{C}$ through tillage. Although there was no difference between treatments in the percentage of change in total soil carbon, longer term studies are needed to see whether continued increases in soil carbon occur. Much research has indicated that the improvements in soil quality and increases in total soil carbon under no-till management can take several years (e.g., Groff, 1999; Veenstra, et al. 2006).

\section{Conclusions}

Two years of study suggest that organic no-till vegetable production might not maximize the yield of all crops on the central coast of California. Experiment 1 resulted in crop failure for zucchini in NT plots and experiment 3 resulted in lower yields of 'Lantern' bell peppers in NT plots compared to T plots. However, other researchers have found no difference in crop yields in no-till plots compared to tilled plots at the Cal Poly 
Organic Farm (Booker, 2009). This indicates the need to continue to evaluate a diversity of crops under reduced tillage management systems.

Choosing the right species as a cover crop or in a cover crop mix might help to optimize no-till systems on the central coast of California. 'Montezuma' red oats flowered earlier and exhibited less re-growth than 'Juan' triticale. A systematic investigation of different cover crop species with regards to their adaptability to no-till on the central coast of California needs to be done.

No-till plots suppressed more weeds than T plots in experiments 1 and 3. This was achieved with less cover crop biomass than is recommended for weed control in organic no-till systems on the east coast of the United States. It is clear that different recommendations need to be created for the central coast of California, where the summers receive little to no rainfall and where growers frequently utilize drip irrigation. Furthermore, this experiment confirms the results found by others that no-till can effectively suppress the germination of certain summer annual weeds (Booker, 2009).

The percentage of total soil carbon generally increased under both treatment types. This indicates that cover cropping might be beneficial to growers regardless of whether the soil is tilled. Longer term studies on permanent organic no-till or rotational till ground are needed to see whether the improvements are sustained or greater under different management systems.

Ultimately, several important questions outside the scope of the current studies need to be addressed in future research to determine the value of organic no-till vegetable production to California's agriculture: How much soil is lost during the dry months to wind erosion under different management systems? What is the cost of production under 
different management systems? Does the mulch layer produced by no-till reduce the amount of water needed by a crop compared to standard tillage? Are there any pest interactions in no-till? To be sure, research on organic no-till vegetable production on the west coast in general is only in its earliest stages. 


\section{References}

Abdul-Baki, A., R. Korcak, and J. Teasdale. 1997. Nitrogen requirements of freshmarket tomatoes on hairy vetch and black polyethylene mulch. HortScience 32(2): 217-221.

Abdul-Baki, A.A., Morse, R.D. and Teasdale, J.R. 1999. Tillage and mulch effects on yield and fruit fresh mass of bell pepper (Capsicum annum L.). Journal of Vegetable Crop Production 51(1): 43-58.

Abdul-Baki, A. and J.R. Teasdale. 1993. A no-tillage tomato production system using hairy vetch and subterranean clover mulches. HortScience 28(2): 106-108.

Abdul-Baki, A.A. and J.R. Teasdale. 1997. Sustainable production of fresh-market tomatoes and other summer vegetables with organic mulches. Farmer's Bulletin 2279. United States Department of Agriculture Agricultural Research Service, Washington DC.

Arshad, M.A., and K.S. Gill. 1997. Barley, canola and wheat production under different tillage-fallow-green manure combinations on a clay soil in a cold, semiarid climate. Soil and Tillage Research. 43(3-4): 263-275.

Blanco-Canqui, H., and R. Lal. 2008. No-tillage and soil-profile carbon sequestration: An on-farm assessment. Soil Science Society of America Journal 72:693-701.

Booker, B. 2009. No-till Tomato Production. Master's thesis, California Polytechnic State University, San Luis Obispo.

Brady, N.C. and R.R.Weil, 2004. Elements of the nature and properties of soils. $2^{\text {nd }}$ ed. Pearson Education, Inc., Upper Saddle River, New Jersey. 
Brennan, E.B. and R.F. Smith. 2005. Winter cover crop growth and weed suppression on the central coast of California. Weed Technology 19(4): 1017-1024.

Carrera L.M., A. Abdul-Baki, J. Teasdale. 2004. Cover crop management and weed suppression in no-tillage sweet corn production. HortScience 39(6): 1262-1266.

Creamer, N.G., B. Plassman, M.A. Bennett, R.K. Wood, R.B. Stinner, and J. Cardina. 1995. A method for mechanically killing cover crops to optimize weed suppression. American Journal of Alternative Agriculture 10:157-162.

Creamer, N.G. 1999. Organic Farming Research Foundation [Online]. Final project report: an evaluation of summer cover crops as weed suppressive mulches in vegetables. Available at http://ofrf.org/funded/reports/creamer_95-54.pdf (verified 10 May 2010).

Fawcett, R. and S. Caruana. 2001. Conservation Technology Information Center [Online]. Better soil better yields: a guidebook to improving soil organic matter and infiltration. Available at http://www.conservationinformation.org/Publications/BetterSoilBetterYields.pdf (verified 10 Feb. 2009).

Gaskell, M., and R. Smith. 2007. Nitrogen sources for organic vegetable crops. HortTechnology 17:431-441.

Groff, S. 1999. Cedar Meadow Farms [Online]. Farm research. Available at http://www.cedarmeadowfarm.com/FarmResearch/ (verified 1 May 2010).

Hartz, T., M. Cantwell, M. LeStrange. 2008. UC Davis Agriculture and Natrual Resources Catalog [Online]. Bell pepper production in California. Available at http://anrcatalog.ucdavis.edu/pdf/7217.pdf (verified 10 May 2010). 
Infante, M. L., and R.D. Morse. 1996. Integration of no-tillage and overseeded legume living mulches for transplanted broccoli production. HortScience 31:376 -380.

Jeavons, J. 1991. How to grow more vegetables: than you ever thought possible on less land than you can imagine. Ecology Action. Palo Alto, CA.

Kuepper, G. 2001. ATTRA [Online]. Organic matters series: pursuing conservation tillage systems for organic crop production. Available at http://attra.ncat.org/attrab/organicmatters/conservationtillage.html (verified 10 May 2010).

Le Strange, Mitchell, W.L. Schrader, and T.K. Hartz. 2000. Fresh-market tomato production in California. Publication 8017, Regents of the University of California, Oakland.

Liebman, M., and C.P. Staver. 2001. Crop diversification and weed management. p. 335. In Ecological management of agricultural weeds. Cambridge University Press, United Kingdom.

Miles, A. and M. Brown. 2003. UCSC Center for Agroecology and Sustainable Food Systems [Online]. Teaching organic farming and gardening: irrigation principles and practices. Available at http://casfs.ucsc.edu/education/instruction/tofg/download/unit_1.5_irrigation.pdf (verified 10 May 2010).

Mitchell, J.P., R.J. Southard, N.M. Madden. 2008. Transition to conservation tillage evaluated in San Joaquin cotton and tomato rotations. California Agriculture 62(2): 74-79. 
Morse, R. 2006. Organic Farming Research Foundation [Online]. Project report: using high-residue cover crop mulch for weed management in organic no-till potato production systems. Available at http://ofrf.org/funded/reports/morse_03s18.pdf (verified 10 may 2010).

Morse, R. and M. Schonbeck. 2007. Virginia Association for Biological Farming [Online]. Information sheet: reduced tillage and cover cropping systems for organic vegetable production. Available at http://www.vabf.org/infosheets/9-07.pdf (verified 10 May 2010).

Myers, N. 1993. Gaia: An atlas of planet management. Anchor/Doubleday, Garden City, New York.

Ngouajio, M., M. McGiffen, and C.M. Hutchinson. 2003. Effect of cover crop and management system on weed populations in lettuce. Crop Prot. 22:57-64.

Potter, K. N., H. A. Torbert, and O. R. Jones. 1998. Distribution and amount of soil organic $\mathrm{C}$ in long-term management systems in Texas. Soil Tillage Res 43: 131-67.

Purakayastha, T. J., D. R. Huggins, and J. L. Smith. 2008. Carbon sequestration in native prairie, perennial grass, no-till, and cultivated Palouse silt loam. Soil Science Society of America Journal 72: 534-540.

Sainju, U. M., B. P. Singh, and S. Yaffa. 2001. Soil organic matter and tomato yield following tillage, cover cropping, and nitrogen fertilization. Tillage and Cropping Systems 94(3).

Schonbeck, M., P. Elder, and R. DeGregorio. 1995. Winter annual cover crops for the home food garden. Journal of Sustainable Agriculture 6(2): 29-53. 
Schomberg, H.H., P.B. Wood and W.L. Hargrove. 1994. Influence of crop residues on nutrient cycling and soil chemical properties p. 99-121. In P.A. Unger (ed.) Managing agricultural residues. Lewis Publ. Boca Raton, FL.

Sparks, D. L. 1996. Carbon and nitrogen analysis, p. 961-1010. In Methods of soil analysis part 3: Chemical methods. Soil Science Society of America. Madison, WI.

Sullivan, P. 2003. ATTRA [Online]. Fundamental of sustainable agriculture: overview of cover crops and green manures. Available at http://attra.ncat.org/attrapub/PDF/covercrop.pdf (verified 10 May 2010).

Sullivan, P.G., D.J. Parish, and J.M. Luna. 1991. Cover crop contributions to N supply and water conservation in corn production. American Journal of Alternative Agriculture 6: 106-107.

Veenstra, J. J., W. R. Horwath, J.P. Mitchell, and D.S. Munk. 2006. Conservation tillage and cover cropping influence soil properties in San Joaquin valley cotton-tomato crop. California Agriculture 60(3): 146-153.

Walz, E. 2004. Organic Farming Research Foundation [Online] Fourth national organic farmers' survey: sustaining organic farms in a changing organic marketplace. Available at http://ofrf.org/publications/survey.html (verified 10 May 2010). 


\section{Appendices}

\section{Appendix A: Timetable for experiments}

\section{Experiment 1}

Date

November 1, 2007

March 3, 2008

March 4, 2008

March 5, 2008

April 14, 2008

June 1, 2008

June 15 - July 13, 2008

Experiment 2

Date

November 3, 2007

March 21, 2008

April 7, 2008

March 21 - May 1, 2008

\section{Experiment 3}

Date

December 15, 2008

March 31, 2009

April 1, 2009

April 3, 2009

April 4, 2009

April 14, 2009

April 28, 2009

April 29, 2009

April 31, 2009

June 18, 2009

June 19, 2009

July 4 - August 14, 2009

September 8 - November 22, 2009

\section{Cultural Practice}

Cover crop planted

Cover crop samples taken

Tilled plots rotary mown, disk ploughed

No-till plots sickle-bar mown

Tilled plots disk ploughed, beds shaped

'Ambassador' zucchini planted

Weeds counted
Cultural Practice

Cover crops planted

Sampled Montezuma Red Oats for biomass

Sampled Juan Triticale for biomass

Monitored re-growth of over crops

\section{Cultural Practice}

\section{Cover crop planted}

Cover crop samples taken

Tilled plots flail mown

Pepper seeds planted in trays in greenhouse

No-till plots scythed

Tilled plots overhead irrigated, forked

Tilled plots forked

Tilled plots roto-tilled

Composite soil sample taken

Pre-irrigated plots

Transplanted bell peppers

Weed data recorded

Harvested peppers 


\section{Appendix B: United States standards for grades of sweet peppers}

\section{Corrected and Effective November 17, 2005}

${ }_{1}$ Packing of the product in conformity with the requirements of these standards shall not excuse failure to comply with the provisions of the Federal Food, Drug, and Cosmetic Act.

\section{United States Standards for Grades of Sweet Peppers 1}

Corrected and Effective November 17, 2005

\section{Grades}

51.3270 U.S. Fancy.

51.3271 U.S. No. 1.

51.3272 U.S. No. 2.

\section{Reserved}

51.3273 [Reserved].

\section{Tolerances}

51.3274 Tolerances.

\section{Application of Tolerances}

51.3275 Application of tolerances.

\section{Definitions}

51.3276 Mature green.

51.3277 Similar varietal characteristics.

51.3278 Firm.

51.3279 Well shaped.

51.3280 Injury.

51.3281 Fairly well shaped.

51.3282 Damage.

51.3283 Not seriously misshapen.

51.3284 Serious damage.

51.3285 Diameter.

51.3286 Length.

\section{Grades}

$\$ 51.3270$ U.S. Fancy.

"U.S. Fancy" consists of mature green sweet peppers of similar varietal characteristics (except when

more than one variety and/or color are marked on the container), which are firm, well shaped, and free

from sunscald, freezing injury, decay affecting calyxes and/or walls, decay affecting stems, and from injury caused by scars, hail, sunburn, disease, insects, mechanical or other means.

(a) Size. The diameter of each pepper shall be not less than 3 inches and the length of each pepper

shall be not less than 3-1/2 inches.

(b) Color. Any lot of peppers which meets all the requirements of this grade, except those relating to

green color, may be designated as "U.S. Fancy" with the characteristic color specified in connection with 
this grade, provided that at least 90 percent of the peppers show any amount of the specified characteristic color, and provided further, that if the peppers fail to meet the color requirements of either

"U.S. Fancy" or "U.S. Fancy (color specified)," they may, when requested, be designated as "U.S. Fancy

Mixed Color" (See Tolerances, §51.3274).

\section{$\S 51.3271$ U.S. No. 1.}

"U.S. No. 1" consists of mature green sweet peppers of similar varietal characteristics (except when

more than one variety and/or color are marked on the container), which are firm, fairly well shaped, and free from sunscald and decay affecting calyxes and/or walls, decay affecting stems, and free from damage caused by freezing injury, hail, scars, sunburn, disease, insects, mechanical or other means.

(a) Size. Unless otherwise specified, the diameter of each pepper shall be not less than 2-1/2 inches and the length of each pepper shall be not less than 2-1/2 inches.

(b) Color. Any lot of peppers which meet all the requirements of this grade, except those relating to

green color, may be designated as "U.S. No. 1" with the characteristic color specified in connection with

this grade, provided that at least 90 percent of the peppers show any amount of the specified characteristic color, and provided further, that if the peppers fail to meet the color requirements of either

"U.S. No. 1" or "U.S. No. 1 (color specified)," they may, when requested, be designated as "U.S. No. 1

Mixed Color" (See Tolerances, §51.3274).

\section{\$51.3272 U.S. No. 2.}

"U.S. No. 2" consists of mature green sweet peppers of similar varietal characteristics (except when

more than one variety and/or color are marked on the container), which are firm, not seriously misshapen, and free from sunscald and decay affecting calyxes and/or walls, decay affecting stems, and

free from serious damage caused by freezing injury, hail, scars, sunburn, disease, insects, mechanical or other means.

(a) Color. Any lot of peppers which meet all the requirements of this grade, except those relating to

green color, may be designated as "U.S. No. 2" with the characteristic color specified in connection with

this grade, provided that at least 90 percent of the peppers show any amount of the specified characteristic color, and provided further that if the peppers fail to meet the color requirements of either

"U.S. No. 2" or "U.S. No. 2 (color specified)," they may, when requested, be designated as "U.S. No. 2

Mixed Color" (See Tolerances, §51.3274).

\section{Reserved}

\section{$\S 51.3273$ [Reserved].}

Tolerances

$\S 51.3274$ Tolerances.

In order to allow for variations incident to proper grading and handling in each of the foregoing grades, the following tolerances, by count, are provided as specified: 
(a) U.S. Fancy and U.S. No. 1 grades.

(1) For defects. Not more than a total of 10 percent of the peppers in any lot may fail to meet the requirements of these grades, but not more than one-half of this amount, or 5 percent, shall be allowed for peppers which are seriously damaged, including therein not more than 2 percent for peppers affected

by decay affecting calyxes and/or walls; and,

(2) For off-size. Not more than 10 percent of the peppers in any lot may fail to meet the size specifications.

(b) U.S. No. 2 grade.

(1) For defects. Not more than a total of 10 percent of the peppers in any lot may fail to meet the requirements of this grade, but not more than one-half of this amount, or 5 percent, shall be allowed for peppers affected by sunscald or affected by decay affecting stems only, including therein not more than

2 percent for peppers affected by decay affecting calyxes and/or walls.

\section{Application of Tolerances}

$\$ 51.3275$ Application of tolerances.

The contents of individual packages in the lot, based on sample inspection, are subject to the following

limitations: Provided, that the averages for the entire lot are within the tolerances specified for the grade:

(a) For packages which contain more than 20 peppers, and a tolerance of 10 percent or more is provided, individual packages in any lot shall have not more than one and one-half times the tolerance specified.

(b) For packages which contain more than 20 peppers and a tolerance of less than 10 percent is provided, and for packages which contain 20 peppers or less, individual packages in any lot shall have

not more than double the tolerance specified, except that at least 1 defective and 1 off-size pepper may

be permitted in any package.

\section{Definitions}

\section{$\$ 51.3276$ Mature green.}

"Mature green" means that the pepper has reached the stage of development that will withstand normal

handling and shipping.

\section{$\$ 51.3277$ Similar varietal characteristics.}

"Similar varietal characteristics" mean that each pepper is of the same general type (except when more than one variety and/or color are marked on the container). For example, thin walled types and thick walled types of the same color shall not be mixed within the container.

\section{$\$ 51.3278$ Firm.}

"Firm means" that the pepper is not soft, shriveled, limp or pliable, although it may yield to slight pressure.

\section{$\S 51.3279$ Well shaped.}

"Well shaped" means that the pepper is not more than slightly curved, slightly indented or not otherwise

more than slightly misshapen. 


\section{$\$ 51.3280$ Injury.}

"Injury," unless otherwise specifically defined in this section, means any defect which more than slightly

detracts from the appearance, or the edible or shipping quality of the pepper. Any one of the following

defects, or any combinations of defects the seriousness of which exceeds the maximum allowed for any

one defect, shall be considered as injury:

(a) Scars when scattered over the surface and aggregating more than the area of a circle fiveeighths

inch in diameter or one scar three-eighths inch in diameter on a pepper 3-1/2 inch in length and 3 inches

in diameter, or correspondingly greater areas of scars on larger peppers;

(b) Sunburn when causing discoloration which affects an aggregate area exceeding 5 percent of the

surface of the pepper;

(c) Bacterial Spot when aggregating more than the area of a circle five-eighths inch in diameter

on a

pepper 3-1/2 inch in length and 3 inches in diameter, or correspondingly greater areas of spots on larger peppers; and,

(d) Hail or similar injury when the skin is healed and the affected areas aggregate more than the equivalent of a circle three-eighths inch in diameter on a pepper 3-1/2 inch in length and 3 inches in

diameter, or correspondingly greater areas of injury on larger peppers.

\section{\$51.3281 Fairly well shaped.}

"Fairly well shaped" means that the pepper may be more than slightly indented or curved, but is not of

the type commonly known as "button" or is not decidedly crooked, constricted or deformed.

\section{$\$ 51.3282$ Damage.}

"Damage," unless otherwise specifically defined in this section, means any defect which materially

detracts from the appearance, or the edible or shipping quality of the pepper. Any one of the following

defects, or any combinations of defects the seriousness of which exceeds the maximum allowed for any

one defect, shall be considered as damage:

(a) Scars when scattered over the surface and aggregating more than the area of a circle fiveeighths

inch in diameter or one scar three-eighths inch in diameter on a pepper 2-1/2 inch in length and

$2-1 / 2$

inches in diameter, or correspondingly lesser or greater areas of scars on smaller or larger peppers;

(b) Sunburn when causing discoloration which affects an aggregate area exceeding 15 percent of the

surface of the pepper;

(c) Bacterial Spot when aggregating more than the area of a circle five-eighths inch in diameter on a pepper 2-1/2 inch in length and 2-1/2 inches in diameter, or correspondingly lesser or greater areas of

spots on smaller or larger peppers; and,

(d) Hail or similar injury when the skin is healed and the affected areas aggregate more than the 
equivalent of a circle three-eighths inch in diameter on a pepper 2-1/2 inch in length and 2-1/2 inches in

diameter, or correspondingly lesser or greater areas of injury on smaller or larger peppers.

\section{$\$ 51.3283$ Not seriously misshapen.}

"Not seriously misshapen" means that the pepper is not badly indented, crooked, constricted or otherwise badly deformed.

\section{$\$ 51.3284$ Serious damage.}

"Serious damage," unless otherwise specifically defined in this section, means any defect which seriously detracts from the appearance or the edible or shipping quality of the pepper. Any one of the

following defects, or any combinations of defects the seriousness of which exceeds the maximum allowed for any one defect, shall be considered as serious damage:

(a) Sunscald;

(b) Any opening or puncture through the fleshy wall of the pepper;

(c) Scars when scattered over the surface and aggregating more than the area of a circle 1 inch in

diameter or one scar three-fourths inches in diameter on a pepper 2-1/2 inch in length and 2-1/2 inches

in diameter, or correspondingly lesser or greater areas of scars on smaller or larger peppers;

(d) Sunburn when causing discoloration which affects an aggregate area exceeding 25 percent of the

surface of the pepper;

(e) Bacterial Spot when aggregating more than the area of a circle 1 inch in diameter on a pepper $2-1 / 2$

inch in length and 2-1/2 inches in diameter, or correspondingly lesser or greater areas of spots on smaller or larger peppers; and,

(f) Decay affecting stems only.

\section{$\$ 51.3285$ Diameter.}

"Diameter" means the greatest dimension measured at right angles to the longitudinal axis.

\section{\$51.3286 Length.}

"Length" means the greatest overall length measured in a straight line parallel to the longitudinal axis,

exclusive of the stem. 


\section{Appendix C: Results from pre-plant soil test for bell peppers}

May 13, 2009

\section{Cal Poly State University}

Crop Science Department

1 Grand Avenue
Lab ID Customer ID

: SP 0904305-001 :

$2-13300$

Sampled On

Sampled By
: April 29, 2009

: Nathan

Harkleroad

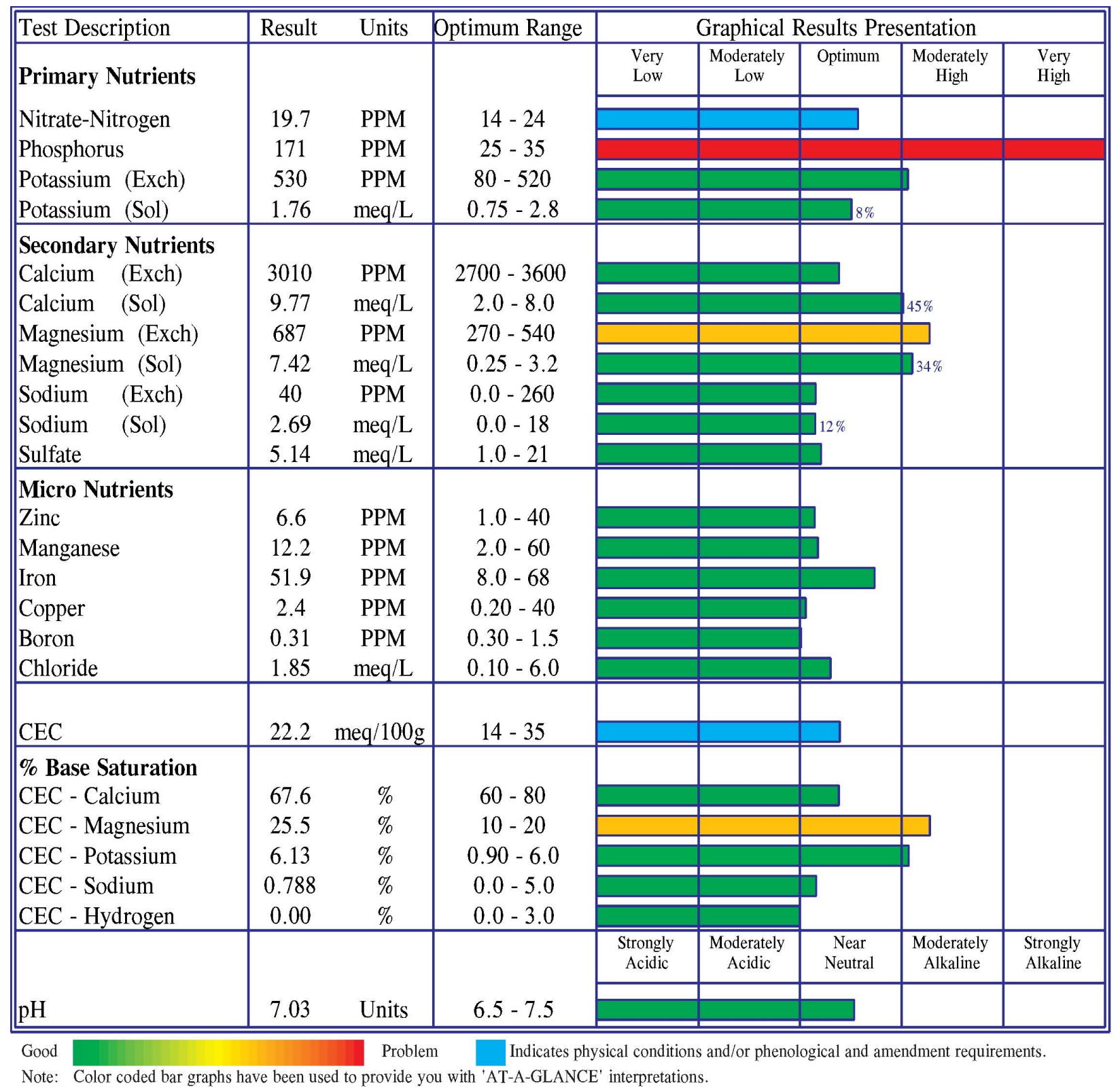

